\title{
EDUKASI PENGETAHUAN SANITASI PADA PRODUKSI KERUPUK IKAN DI UD SUMBER REJEKI SURABAYA
}

\section{EDUCATION SANITATION KNOWLEDGE ON FISH CRACKER AT UD SUMBER REJEKI SURABAYA}

\author{
Andre Yusuf Trisna Putra ${ }^{1 *}$, Nove Kartika Erliyanti ${ }^{2)}$, Ira Wikartika ${ }^{3)}$ \\ ${ }^{1)}$ Fakultas Teknik, Universitas Pembangunan Nasional Veteran Jawa Timur \\ email: andreyusuf.tp@upnjatim.ac.id \\ ${ }^{2)}$ Fakultas Teknik, Universitas Pembangunan Nasional Veteran Jawa Timur \\ email: nove.kartika.nke.tk@upnjatim.ac.id \\ ${ }^{3)}$ Fakultas Ekonomi dan Bisnis, Universitas Pembangunan Nasional Veteran Jawa Timur \\ email: irawikartika@upnjatim.ac.id
}

\begin{abstract}
ABSTRAK
Sanitasi makanan adalah kegiatan yang dilakukan untuk membebaskan makanan dari kontaminasi makanan sehingga makanan tetap aman selama proses produksi makanan mulai dari penanganan bahan baku sampai distribusi produk kepada konsumen. Pengetahuan sanitasi sangat penting dimiliki oleh para pelaku industri makanan terutama pemilik usaha mikro kecil dan menengah (UMKM). Pengetahuan sanitasi yang baik akan mendukung terciptanya produk yang bersih, aman bebas dari bahaya kesehatan. Edukasi tentang sanitasi makanan dilakukan kepada UD Sumber Rejeki yang bergerak pada produksi kerupuk ikan di kota Surabaya. Pelaksanaan pengabdian masyarakat berlangsung dalam dua tahap. Tahap pertama adalah proses koordinasi dengan mitra untuk melaksanakan rangkaian kegiatan. Tahap kedua adalah kegiatan inti yang terdiri dari pre-test, edukasi dan post-test. Materi yang disampaikan antara lain personal hygiene, sanitasi peralatan, dan sanitasi ruangan. Hasil pengamatan setelah kegiatan menunjukkan bahwa penerapan sanitasi yang ada di UD Sumber Rejeki terjadi peningkatan positif. Pengetahuan tentang sanitasi meningkat dari $62 \%$ menjadi $82 \%$ dan pada penerapannya meningkat dari $44 \%$ menjadi $56 \%$. Dari hasil kegiatan tersebut dapat dikatakan bahwa edukasi dalam bentuk penyuluhan merupakan salah satu cara efektif dalam menyampaikan materi sanitasi pada mitra. Hasil positif yang dicapai yaitu peningkatan pengetahuan sanitasi sebesar $10 \%$ dan penerapan program sanitasi sebesar $12 \%$.
\end{abstract}

Kata kunci: Kerupuk Ikan, Sanitasi, UMKM

\section{ABSTRACT}

Food sanitation is the practice of following certain rules and procedures to prevent the contamination of food, keeping it safe to eat during food processing from material handling to distribution. Sanitation knowledge is very important for food industry, especially UMKM (usaha kecil mikro dan menengah). Sanitation supports food products that are clea, safe and free from health hazards. Education was carried out to UD Sumber Rejeki, fish cracker industry in Surabaya. The program is implemented in two stages. The first stage is coordination with partner. The second stage consist of pre-test, counseling, and post-test. The content delivered includes personal hygiene, equipment sanitation and room sanitation. The result of post-activity observation showed that implementation of sanitation in UD Sumber Rejeki had a postif increase. Knowledge of sanitation increased from $62 \%$ to $82 \%$ and in practice increased from $44 \%$ to $56 \%$. From the results of this activities, it can be said that counseling is an effective way to convey to sanitation knowledge to partners. Postif results were achieved for sanitation knowledge by $10 \%$, and implemention of sanitation program by $12 \%$.

Keywords: Fish Cracker, Sanitation, UMKM 
PENDAHULUAN

Kasus berkenaan keracunan pangan di Indonesia masih sering terjadi. Beberapa diantaranya diberitakan Harian Kompas. Diberitakan harian kompas edisi [1] Yakobus Neolaka, warga Nusa Tenggara Timur, beserta kerabatnya mengalami keracunan setelah mengonsumsi daging kambing. Selain itu, keluarga di Desa Muria, Aceh Utara mengalami keracunan jengkol usai makan sahur. Hal ini membuktikan bahwa pengetahuan tentang keamanan pangan menjadi salah satu hal penting yang harus diketahui oleh masyarakat Indonesia. Menurut Peraturan Pemerintah Republik Indonesia Nomor 86 Tahun 2016 tentang keamanan, mutu dan gizi pangan, Keamanan Pangan (Food Safety) adalah kondisi dan upaya yang diperlukan untuk mencegah pangan dari kemungkinan cemaran biologis, kimia dan benda lain yang dapat mengganggu, merugikan, dan membahayakan kesehatan manusia.

Pertumbuhan jumlah usaha yang bergerak di bidang pengolahan makan memberikan keuntungan banyak pihak termasuk konsumen [2]. Namun demikian, dalam praktik di lapangan belum banyak produsen makanan yang memiliki pengetahuan cara produksi pangan yang baik, terutama dalam hal sanitasi proses produksi. Akibatnya, kontaminasi fisik seperti rambut, kerikil, dan besi sering terjadi pada produk makanan terutama oleh industri rumahan atau UMKM. Oleh karena itu, pengetahuan sanitasi menjadi hal yang sangat penting bagi pada pelaku UMKM yang bergerak di industri produksi makanan.

UD Sumber Rejeki adalah salah satu UMKM yang memproduksi kerupuk ikan di kota Surabaya. Usaha ini dikelola oleh Ibu Lianah dan anaknya Norizul Inayah. UD Sumber Rejeki memproduksi bermacammacam variasi olahan kerupuk ikan seperti kerupuk kerang, kerupuk lele, kerupuk bayam, kerupuk spesial ikan payus, ikan bandeng, kerupuk lele, kerupuk bayam payus, kerupuk udang, kerupuk buah mangrove. Dari hasil survei pendahuluan dapat diketahui bahwa proses produksi kerupuk ikan menggunakan peralatan sederhana dan belum sesuai dengan kaidah hygiene dan sanitasi makanan [3].

Kekurangan dana untuk modal kerja maupun investasi menjadi salah satu faktor penghambat yang dihadapi hampir seluruh UMKM untuk memproduksi makanan dengan layak [4]. Selain itu, UMKM juga menghadapi keterbatasan akses terhadap informasi, layanan dan fasilitas oleh pemerintah tentang pentingnya penerapan hygiene dan sanitasi. Oleh karena itu, perlu adanya pihak yang berperan sebagai konsultan, atau partner sharing bagi para pelaku UMKM memecahkan permasalahan yang dihadapi.

Perguruan tinggi dapat berperan mentransformasikan pengetahuan dan teknologi guna memecahkan permasalahan yang dihadapi oleh UMKM. Pihak perguruan tinggi dapat membangun hubungan kerja dengan UKM sebagai konsultan ahli. Oleh 
karena itu, tujuan dari kegiatan pengabdian kepada masyarakat (PKM) ini memberikan edukasi pengetahuan sanitasi pada produksi kerupuk ikan di UD Sumber rejeki. Untuk mengetahui efektivitas kegiatan dilakukan penyebaran kuesioner pre-test dan post test yang berfokus pada tema sanitasi sehingga keberhasilan kegiatan dapat diukur.

\section{METODE PELAKSANAAN KEGIATAN}

Kegiatan PKM dilaksanakan pada 10 Agustus- 12 September 2021, bertempat di UD Sumber Rejeki, Jl. Gununganyar Tambak 1/No. 63, RT02, RW012, Kel. Gununganyar Tambak, Kec. Gunung Anyar, Kota Surabaya. Kegiatan PKM berlangsung dalam dua tahap. Tahap pertama adalah proses koordinasi dengan mitra untuk melaksanakan rangkaian kegiatan. Tahap kedua adalah kegiatan inti yang terdiri dari pre-test, edukasi dan post-test.

Metode pelaksanaan kegiatan inti adalah pertama mitra yang berjumlah 5 responden diberikan pre-test dalam bentuk kuesioner yang terdiri dari 17 pertanyaan. Mitra diminta untuk menjawab pertanyaan dengan memberikan tanda $(\sqrt{ })$ pada pilihan (YA) atau (TIDAK). Kedua, materi edukasi tentang sanitasi diberikan dengan metode diskusi dan dibantu dengan materi dalam bentuk print out. Tahap ketiga, post-test dilaksanakan dalam kurun waktu 1 bulan setelah kegiatan pre-test dan edukasi berakhir.

\section{HASIL DAN PEMBAHASAN}

\section{Pretest}

Kegiatan pre-test bertujuan untuk mengetahui sejauh mana wawasan mitra tentang sanitasi pada usaha produksi kerupuk ikan. Materi pre-test dibagi menjadi dua sub tema yaitu pengetahuan sanitasi dan penerapan sanitasi dengan total 17 pertanyaan. Jawaban YA menunjukkan bahwa mitra mengetahui jawaban dari soal kuesioner, sedangkan jawaban TIDAK menunjukkan mitra tidak mengetahui jawaban soal kuesioner. Hasil pre-test disajikan pada Gambar 1.

Gambar 1 menunjukkan bahwa hasil pengetahuan mitra terhadap teori sanitasi sebesar 62\%. Dari hasil tersebut, dapat diketahui bahwa mitra cukup mengetahui prinsip penerapan sanitasi seperti memakai sarung tangan, melepaskan perhiasan serta menjaga kebersihan peralatan selama memproduksi makanan. Namun demikian, penerapan sanitasi menunjukkan nilai $44 \%$. Mitra tidak sepenuhnya menjalankan program sanitasi yang telah mereka ketahui. Beberapa kendala diantaranya adalah mitra tidak mengetahui pengetahuan tentang sanitasi secara detail, tidak mempunyai peralatan yang seusai standar, dan kondisi ruangan yang terbatas. Hasil ini sesuai [5] yang menyatakan bahwa pengetahuan sanitasi berhubungan dengan penerapan hygiene personal, namun tidak secara langsung berkontribusi terhadap penerapan sanitasi secara keseluruhan. 


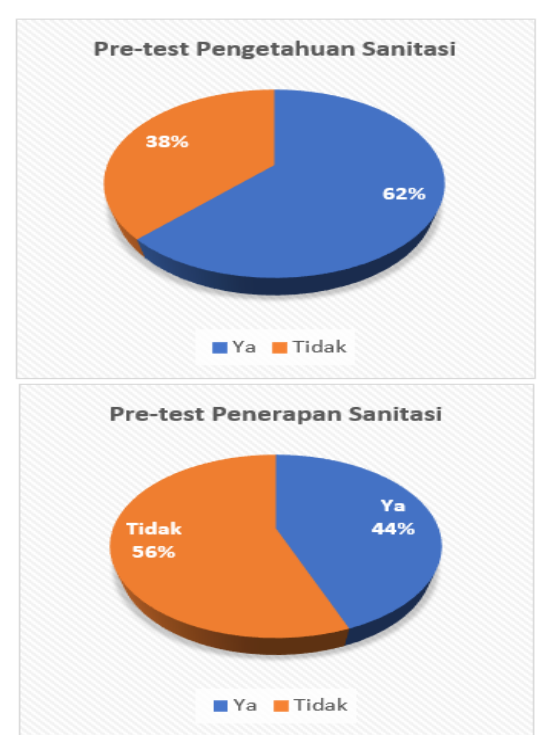

Gambar 1. Hasil Pre-test Pengetahuan sanitasi (a) dan Penerapan Sanitasi (b)

\section{Post Test}

Post-test diberikan saat monitoring terakhir kegiatan PKM. Post-test bertujuan untuk mengukur keberhasilan edukasi sanitasi yang diberikan selama kegiatan PKM. Kuesioner yang diberikan pada saat pre-test dan post-test adalah sama. Hasil post-test tentang pengetahuan dan penerapan sanitasi produksi kerupuk ikan disajikan pada Gambar 2.

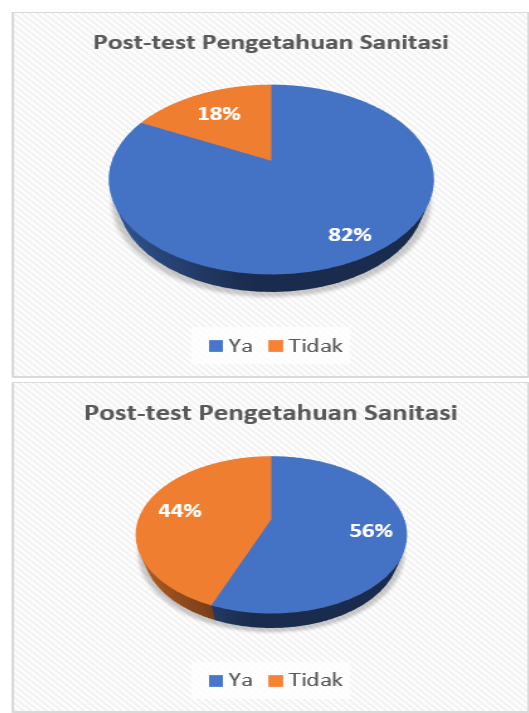

Gambar 2. Hasil Post-test Pengetahuan Sanitasi (a) dan Penerapan Sanitasi (b)
Pada Gambar 2. menunjukkan bahwa hasil post-test pengetahuan mitra meningkat dari $62 \%$ menjadi $82 \%$, sedangkan penerapan sanitasi juga meningkat dari $44 \%$ menjadi $56 \%$. Mitra lebih memahami gambaran secara mendetail tentang pentingnya sanitasi terhadap kualitas makanan yang dihasilkan. Peningkatan penerapan program sanitasi pada mitra banyak terjadi pada aspek sanitasi ruangan seperti membersihkan ruangan secara berkala, memisahkan bahan baku utama dan pembantu, dan penataan ruangan yang lebih rapi.

\section{Kegiatan Edukasi Sanitasi}

Pemberian materi edukasi sanitasi disampaikan dalam bentuk ceramah dan diskusi selama 30 menit. Tujuan dari kegiatan ini adalah untuk meningkatkan pengetahuan mitra tentang konsep sanitasi yang meliputi personal hygiene, sanitasi peralatan dan sanitasi yang baik dan benar sehingga dapat diterapkan pada usaha yang dijalankan. Kegiatan PKM ini juga dibantu 2 orang mahasiswa Program Studi Teknologi Pangan dan Teknik Kimia. Untuk mempermudah penyampaian materi, tim penyuluh memberikan print-out yang berisi teori dan cara pelaksanaan sanitasi yang disesuaikan dengan usaha produksi kerupuk ikan. Printout tersebut berisi gambaran umum tentang sanitas, pelaksanaan hygiene personal dan sanitasi peralatan dan sanitasi ruangan.

Hasil pengamatan pasca kegiatan PKM bahwa penerapan sanitasi/hygiene personal yang ada di UD Sumber Rejeki terjadi peningkatan positif. Hal ini dapat dilihat dari 
peningkatan hasil dari hasil pada pengetahuan meningkat dari $62 \%$ menjadi $82 \%$ dan pada penerapan meningkat dari 44\% menjadi $56 \%$. Peningkatan penerapan sanitasi dapat dilihat pada Gambar. Hasil positif ini sejalan dengan [2], semakin banyak orang yang mengetahui, memperhatikan, memelihara, dan meningkatkan kegiatan sanitasi dapat mengurangi terjadinya kontaminasi silang yang dapat menjadi sumber penularan penyakit.

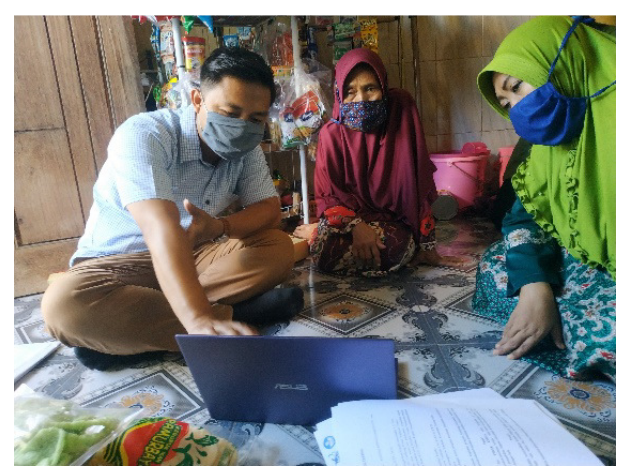

(a)

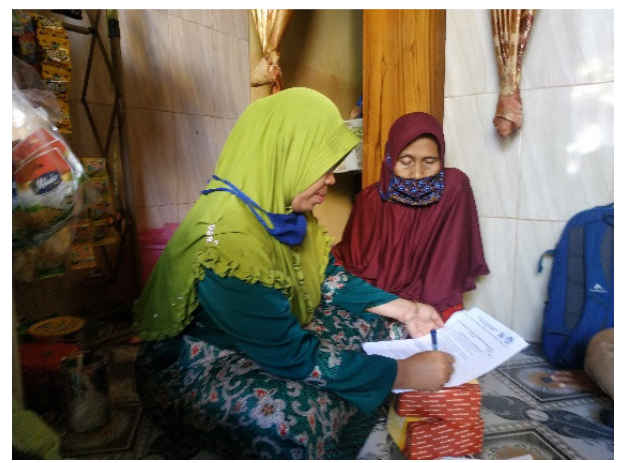

(b)

Gambar 3. Kegiatan PKM (a) pemberian materi oleh penyuluh, (b) pengerjaan kuesioner oleh mitra
Pada personal hygiene tim penyuluh menekankan pada beberapa materi seperti mencuci tangan dengan air dan sabun sebelum dan sesudah bekerja, memakai penutup rambut, memakai sarung tangan, dan memakai pakaian kerja/celemek, dan menghindari penggunaan make up yang berlebih. Personal hygiene adalah salah satu kunci program sanitasi para pejamah makanan. Menurut [6] personal hygiene adalah kebersihan dan kesehatan perorangan yang bertujuan untuk mencegah timbulnya penyakit pada diri sendiri dan orang lain, baik secara fisik maupun psikologis. Personal hygiene dipengaruhi oleh beberapa factor antara lain adalah pendidikan, lingkungan, kebudayaan, dan agama serta preferensi pribadi.

Praktek higiene dan sanitasi makanan dapat menentukan kualitas hygiene dan sanitasi makanan yang didukung dengan fasilitas yang memadai yang menyatakan penjamah makanan masih melakukan perilaku berisiko saat mengolah makanan, seperti tidak menggunakan masker, penutup kepala, sarung tangan, banyak berbicara, menggaruk anggota tubuh dan mengunyah makanan saat sedang mengolah makanan. Perilaku tersebut dapat memperbesar kemungkinan terjadinya kontaminasi pada makanan yang diproduksi [5]. 

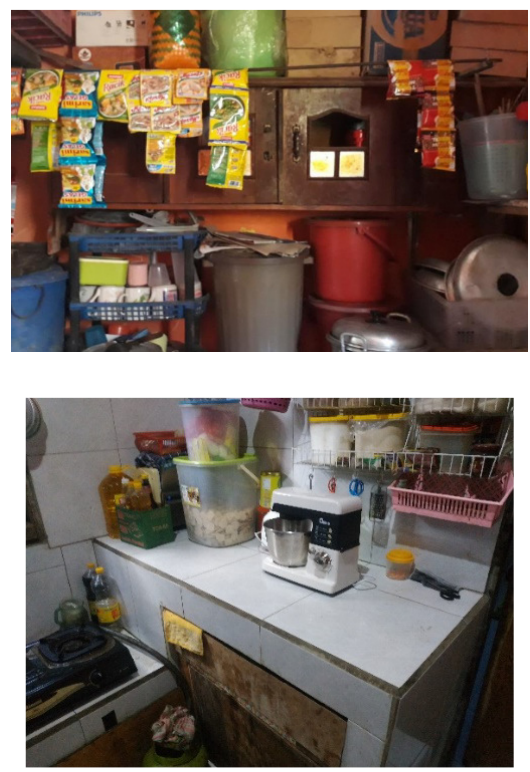

(b)

(a)
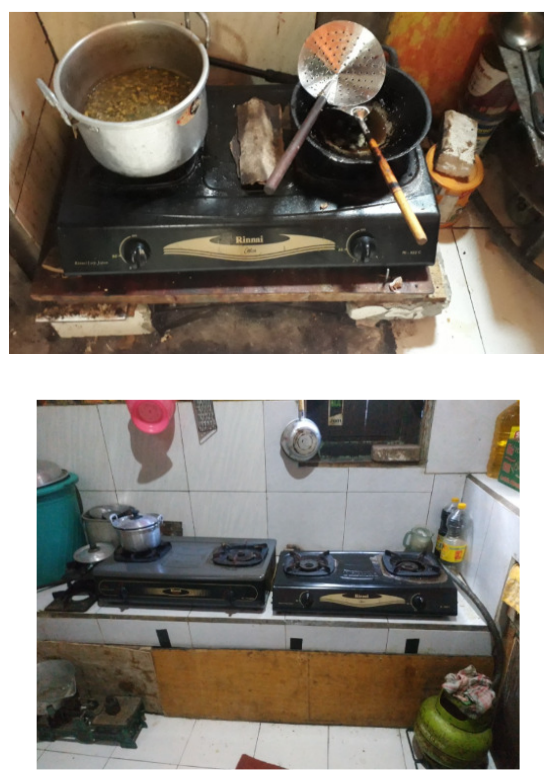

Gambar 4 Kondisi ruangan produksi (a) sebelum kegiatan PKM, (b) setelah kegiatan PKM

Pada materi sanitasi peralatan, tim pengarahan penataan peralatan produksi penyuluh menekankan pada pencucian kepada mitra. Peralatan dikelompokkan peralatan yang diunakan, seperti mencuci alat berdasarkan ukuran dan fungsi penggunaan. dari stainless steel dengan air hangat dan Hasil dari penataan ulang ini dapat sabun, membersihkan dan mengeringkan memudahkan mitra dalam melakukan wadah sebelum dan setelah digunakan dan produksi kerupuk. Hal ini sesuai [7], kegiatan mengecek ketajaman alat pemotong. Hasil PKM yang berfokus pada perbaikan sanitasi yang didapatkan cukup positif karena berdasarkan hasil diskusi, mitra lebih paham pentingnya mengeringkan wadah sebelum dan sesudah digunakan dan selalu mengecek ketajaman alat pemotong.

Ditinjau dari sanitasi ruangan, keterbatasan ruangan produksi menjadi salah satu factor utama yang dihadapi oleh mitra. Namun demikian, penyuluhan tetap memberikan dampak positif yaitu penataan ulang ruang produksi dan penataan bahan bahan yang digunakan untuk produksi kerupuk ikan. Tim penyuluh memberikan dapat berupa pengaplikasian alat yang sesuai standar produk makanan, dan penataan ulang ruangan produksi. Hasil kegiatan PKM dapat menghasilkan produk yang lebih higienis, bermutu dan membantu mempermudah mitra dengan penataan ruang yang lebih baik.

Dari hasil evaluasi PKM terdapat beberapa saran yang dapat diterapkan pada usaha produksi kerupuk ikan UD Sumber Rejeki yaitu 1) perlu ditingkatkan kesadaran dalam melaksanakan personal hygiene 2) alur produksi kerupuk ikan diperbaiki dan ditata ulang seusai urutan produksi kerupuk ikan, 3) 
menggunakan peralatan dan fasilitas

produksi yang food grade.

Dari hasil kegiatan PKM yang telah dilakukan menunjukkan bahwa kegiatan penyuluhan merupakan salah satu cara efektif untuk menambah pengetahuan seseorang tentang suatu konsep pengetahuan. Hal ini dapat terlihat dari meningkatkan tingkat pengetahuan dan penerapan sanitasi pada mitra. Menurut [8] tenaga penyuluh memiliki peran sebagai ujung tombak pelaksanaan penyuluhan. Hasil positif yang didapatkan pasca penyuluhan menunjukkan keberhasilan kegiatan sesuai dengan tujuan yang dicanangkan di lapangan. Beberapa kendala yang sering dihadapi dalam kegiatan penyuluhan antara lain perbedaan norma, agama dan budaya, dna tingkat pendidikan penyuluh dan audiens. Pemanfaatn media baik cetak maupun elektronik dpat digunakan untuk menunjang keberhasilan penyampaian materi.

Edukasi merupakan salah satu cara yang efektif untuk sosialiasi pentingnya sanitasi pada mitra. Edukasi program sanitasi berisi tentang personal hyegiene, sanitasi peralatan sanitasi ruangan. Hasil edukasi menunjukkan hasil positif pada pengetahuan sanitasi sebesar $10 \%$ dan penerapan program sanitasi sebesar $12 \%$ pada mitra.

\section{KESIMPULAN}

Kesimpulan dari kegiatan PKM ini adalah edukasi merupakan salah satu cara yang efektif untuk sosialiasi pentingnya sanitasi pada mitra UD Sumber Rejeki. Edukasi program sanitasi pada UD Sumber
Rejeki berisi tentang personal hyegiene, sanitasi peralatan sanitasi ruangan. Hasil kegiatan PKM, berupa edukasi sanitasi menunjukkan hasil positif pada pengetahuan sanitasi sebesar $10 \%$ dan penerapan program sanitasi sebesar $12 \%$ pada mitra UD Sumber Rejeki.

\section{UCAPAN TERIMAKASIH}

Ucapan Terima Kasih Ucapan terima kasih diberikan kepada Direktorat Riset dan Pengabdian Kepada Masyarakat (DRPM), Kementerian Riset dan Teknologi/Badan Riset dan Inovasi Nasional yang telah mendukung dan memberikan dana hibah pengabdian kepada masyarakat pada skim Program Kemitraan Masyarakat (PKM) 2020. Tim juga berterima kasih kepada UD Sumber Rejeki yang telah bersedia menjadi mitra program PKM.

\section{REFERENSI}

[1] "4 Kasus Keracunan yang Pernah Terjadi, dari Konsumsi Jengkol hingga Umbi Gadung." [Online]. Available: https://www.kompas.com/tren/read/2019 /12/29/123100265/4-kasus-keracunanyang-pernah-terjadi-dari-konsumsijengkol-hingga-umbi.

[2] S. Syahrizal, "Hygiene Sanitasi Penjamah Makanan Terhadap Kandungan Escherichia Coli Diperalatan Makan Pada Warung Makan," AcTion Aceh Nutr. J., vol. 2, no. 2, p. 132, 2017, doi: $10.30867 /$ action.v2i2.67.

[3] N. K. Erliyanti, A. Y. T. Putra, I. Wikartika, D. Prasetyo, R. K. Putra, and N. Inayah, "Penerapan Dan Peningkatan Sanitasi Makanan Pada Produksi Kerupuk Ikan Di Ud Sumber Rejeki Kelurahan Gunung Anyar Tambak Kota Surabaya," LOGISTA - J. Ilm. Pengabdi. Kpd. Masy., vol. 4, no. 2, p. 41, 2020, doi: 10.25077/logista.4.2.41-47.2020.

[4] J. Rahmat and Suryakancana, "Masalah yang dihadapi Usaha Kecil Menengah di 
Indonesia Scanned by CamScanner," Masal. yang dihadapi Usaha Kecil Menengah di Indones., vol. 2 edisi 6, no. January, pp. 11-12, 2016.

[5] E. A. Miranti and A. C. Adi, "Hubungan Pengetahuan Dengan Sikap Dan Higiene Perorangan (Personal Hygiene) Penjamah Makanan Pada Penyelenggaraan Makanan Asrama Putri," Media Gizi Indones., vol. 11, no. $2, \quad$ p. $120, \quad 2018, \quad$ doi: 10.20473/mgi.v11i2.120-126.

[6] P. R. Silalahi V, "Personal Hygiene Pada Anak SD Negeri Merjosari 3," J. Akses Pengabdi. Indones., vol. 2, no. 2, p. 15, 2017.
[7] I. Juliyarsi, S. Melia, and D. Novia, "Perbaikan Sanitasi dan Higienis Kerupuk Kulit IKM Aulia di Kabupaten Agam, Provinsi Sumatera Barat," $J$. Dedik. Masy., vol. 3, no. 1, pp. 26-35, 2019.

[8] E. Anwas, S. Sumardjo, P. Asngari, and P. Tjitropranoto, "Faktor-Faktor yang Mempengaruhi Penyuluh dalam Pemanfaatan Media," J. Komun. Pembang., vol. 7, no. 2, p. 246337, 2009, doi: $10.46937 / 720095689$. 